Portland State University

PDXScholar

$9-18-2018$

\title{
In Service Together: University Students and Incarcerated Youth Collaborate for Change
}

\author{
Deborah Smith Arthur \\ Portland State University, debs@pdx.edu \\ Jamie Valentine \\ Florida State University
}

Follow this and additional works at: https://pdxscholar.library.pdx.edu/studies_fac

Part of the Educational Leadership Commons, and the Educational Methods Commons Let us know how access to this document benefits you.

\section{Citation Details}

Arthur, D. S., \& Valentine, J. (2018). In Service Together: University Students and Incarcerated Youth Collaborate for Change. The Prison Journal, 0032885518776377.

This Post-Print is brought to you for free and open access. It has been accepted for inclusion in University Studies Faculty Publications and Presentations by an authorized administrator of PDXScholar. Please contact us if we can make this document more accessible: pdxscholar@pdx.edu. 
In Service Together:

University Students and Incarcerated Youth Collaborate for Change

\begin{abstract}
Through the lens of two courses at Portland State University, this paper addresses critical service learning pedagogy as transformational for both incarcerated youth and university students. In one course, PSU students share a writing/art workshop with youth in juvenile detention through The Beat Within (www.thebeatwithin.org) Another course brings together PSU students and young men incarcerated at MacLaren Youth Correctional Facility in an Inside Out format (www.insideoutcenter.org). Working together, students have developed a variety of service learning projects. This paper explores the impact of critical service learning courses on both incarcerated young people and university students.
\end{abstract}

Key Words: Critical service-learning, motivational capital, incarcerated youth, civic engagement, juvenile detention

The best way to find yourself is to lose yourself in the service of others.

$\sim$ Mahatma Gandhi 


\section{Background: why service learning matters}

Over the past two decades, ample research has documented and highlighted the positive outcomes of service learning for college students. The National Clearinghouse for Service Learning (2016), defines service learning as "a teaching and learning strategy that integrates meaningful community service with instruction and reflection to enrich the learning experience, teach civic responsibility, and strengthen communities” (https://gsn.nylc.org/clearinghouse). Participating in a meaningful way with and for the community in a service-learning course has been determined to positively impact a variety of academic and nonacademic outcomes including writing skills, critical thinking and problem-solving skills, interpersonal skills, leadership abilities and commitment to activism and civic responsibility (Moely \& Ilustra, 2014; Astin \& Eyler, 2000). Just as service learning courses often are highly beneficial and transformational for college students, civic engagement opportunities and experiences can likewise create positive outcomes for all young adults, including non-college youth. There are tremendous personal and psychological benefits of civic engagement for all young adults during this key transitional period of their lives of late adolescence/early adulthood. Some of these benefits include: participation in collective problem solving, evaluation of personal values, and connection to social networks and other educational and employment opportunities (Flanagan \& Levine, 2010). Additionally, young people who participate in engaged social responsibility activities are more likely to stay civically involved as adults (Flanagan \& Levine, 2010). Unfortunately, however, cumulative disadvantage and differing opportunities to access institutional support affords much less opportunity for civic engagement among low-income and minority young adults (Flanagan \& Levine, 2010).

\section{Civic engagement disparities}


While opportunities for civic engagement for low income and minority youths are limited, opportunities for justice involved youths are limited even more so. However, the benefits of service-learning and civic engagement certainly extend to criminal and juvenile justice system-involved young people as well. There is a growing body of research about the positive implications of meaningful service as a component of a reentry programming for people returning to the community after a period of incarceration. In using the term “meaningful” service, we refer to service involving community engagement that is not simply a required task of menial "community service," such as garbage clean-up, but instead service that involves problem-solving and critical thinking - service that "builds community" (Bazemore \& Boba, 2007, p. 48). In their important article “Civic Engagement Model of Reentry”, Bazemore and Boba (2007) note that civic community service and engagement as reentry practice has a positive impact on reintegration outcomes. Specifically, they argue that civic engagement leads to reduction in recidivism through support for the development of prosocial identities of those experiencing reintegration, the opportunity to reshape the community's image of people who are returning to the community after a period of incarceration, and the development of community capacity for offering informal supports of reentering people (Bazemore \& Boba, 2007). Civic service and engaged social responsibility can transform self-image as well as public image for persons reentering the community, thus "transforming individuals from liabilities to assets” (Bazemore \& Maruna 2009, p. 376). The development of social capital, external supports, and pro-social relationships, all of which can be accessed and developed through engaged civic responsibility opportunities, facilitate a shift toward a noncriminal or non-delinquent identity (Fox, 2016; Lagemann, 2016).

\section{The importance of motivational capital}


Clinkinbeard and Zohra (2012) specifically examine the concept of motivational capital of incarcerated juveniles in their compelling research exploring "expectations, fears and strategies” of juveniles preparing for successful reentry and a life beyond incarceration. They define motivational capital as "a collection of social and cognitive resources which work together to provide momentum for behavior” (Clinkinbeard \& Zhora, 2012, p. 237). Closely linked to the sociological concept of social capital, motivational capital is "the cumulative gathering of motivational resources for behavior” (Clinkinbeard \& Zhora, 2012, p. 237). Indeed, current criminology research to a large extent agrees that the development of social capital is a central factor leading toward desistance from criminal activity (Fox, 2015). Successful community reintegration is partly dependent upon the ability of the formerly incarcerated person to resist criminogenic influences, as well as the receptivity of the community to the re-entering person (Bazemore \& Boba, 2007; Fox, 2016). By engaging in collaborative and meaningful service opportunities, incarcerated people have the opportunity to develop prosocial skills, interests and relationships, while community members have the opportunity to challenge their assumptions and stereotypes about people experiencing incarceration and undergo a shift in perspective that can ultimately contribute to a more just and humane approach to criminal behavior (Hinck, Hinck, \& Withers, 2013). The positive personal benefits of civic engagement are an important factor in the creation of motivational capital for young people experiencing incarceration and preparing to re-enter society, and the benefits to the community participants in these collaborative civic engagement opportunities include the ability to reshape their concept of delinquent and criminal offenders.

\section{Critical service learning pedagogy}


Institutions of higher education are well-positioned to engage in collaborative civic engagement activities with people experiencing incarceration. (Simpkins, 2015; Sokoloff \& Schenck-Fontaine, 2017). Recent scholarship of higher education in prison programs highlights the need for programs that support broad human, intellectual and social outcomes. (Gould, Harkins \& Stevens, 2015). In this paper we examine the outcomes of incarcerated young people and college students developing collaborative service learning projects, through the lens of two college courses. Moving service learning pedagogy a step further, or deeper, both of the courses mentioned here are situated squarely within a critical service learning pedagogy. (Mitchell, 2008). In other words, these courses are about more than being of service or helping someone. They were purposely developed in a way that encourages egalitarian relationships between all students and participants, and asks them to examine and reflect upon the deeper complexities that construct the social justice issues addressed in the courses. Additionally, the experience of working together inside a detention or youth correctional facility situates the learning within a real and applied context. Freire (1998) advocated "reading the world" as a key pedagogical strategy, and the place-based aspects of these critical service-learning experiences allow students to deeply reflect upon that place (juvenile detention or youth correctional facility). This, in turn, has a deep impact upon the relationship of students and participants to that place, and to related policies (Gruenewald, 2003). Indeed, “...firsthand experience [inside carceral institutions housing youth] can become an important way to shape an audience's sensitivity for processing arguments calling for social change regarding the prison-industrial complex...and prepare [students] for a critical examination of incarceration policy" (Hinck, et al, 2013, p. 40). 
In both of the courses mentioned here, all students and participants work together on projects involving critical service-learning. How do these collaborative, critical service-learning experiences impact the college students and the incarcerated students and participants?

Specifically, we examine evidence of interrupted assumptions and perceptions for students and participants in these courses. Has their involvement within these courses, working collaboratively, re-shaped their ideas about each other? Is there evidence of a deeper understanding of the underlying complexities of the context of the courses- both the juvenile justice and criminal justice systems, as well as systems of higher education? Are there shifts in attitudes toward political issues that support mass incarceration as a response to crime? We also examine for evidence of increased motivational capital as a result of these collaborative, critical service-learning experiences. Are students and participants developing prosocial skills and relationships through these courses? Are they developing greater awareness of themselves as civic participants with the ability to be agents of change? And if so, does this identification as change agents empower them in the other aspects of their lives?

\section{A note about "students" and "participants"}

Within this paper we use both the terms "students" and "participants" in reference to incarcerated young people involved in these courses. In the case of the Juvenile Justice Capstone, all the detained youth are between the ages of 12-17, and are still working on high school credits. When their involvement with the Capstone and The Beat Within happens during their school day, they are receiving high school credit for their participation. However, some workshops take place in the evening and on weekends, and participants in those workshops are not receiving academic credit. Unless workshops are integrated into the school day, the detained youth are not required to participate, although most do choose to do so. In the 
Metamorphosis Capstone, the incarcerated young men are typically between the ages of 18-25. Some are enrolled at PSU through this course, and do receive academic credit at PSU. After a relatively lengthy struggle, PSU was convinced to offer differential reduced tuition for inside students enrolled in Inside Out courses offered through PSU, including this one; inside students are billed a flat rate of $\$ 100$ per course. The Oregon Youth Authority covers that tuition for students enrolled in the Metamorphosis Capstone; in the case of partnerships with DOC, individual students are billed. Several of the inside students in Metamorphosis are also enrolled at other institutions of higher education, and PSU works with them to help them transfer credit to the institution that will eventually grant their degree. While the majority of inside students enrolled in the Metamorphosis Capstone choose to take the course for credit, this is not the case for all. The Instructor of the course works closely with OYA and with staff of Hope Partnership/Janus Youth, a non-profit organization that has a strong presence at MYCF, to invite young men into the course who do not necessarily see themselves as college bound. Not surprisingly, many of those young men later re-enroll in the course, for credit.

\section{Positionality of the authors}

Deborah Smith Arthur has been an advocate for justice involved youth for over 25

years. She practiced criminal defense and juvenile law for ten years in the Portland area, and the focus of her work for the latter half of that decade was representing young people, aged 15-17, charged in adult criminal court under Oregon's Ballot Measure 11. Codified in the Oregon Revised Statutes, this measure, passed overwhelmingly by Oregon voters in 1994, created mandatory minimum sentencing upon conviction for certain crimes, and also created automatic waiver to adult criminal court for juveniles charged with these crimes. After that decade as a courtroom lawyer, Smith Arthur began teaching at Portland State University. She developed 
the partnerships described in this paper with the Multnomah County Department of Community Justice, and with the Oregon Youth Authority, and teaches/facilitates both of these courses.

Jamie Valentine comes to this work through personal struggle. Through her own life experiences, she had to self-reflect in order to heal and thrive. She came to accept that she was more than a few negative traits, more than the worst things she has done, and accepted that to grow, she had to find her inner peace. Through this transformational epiphany, she realized that removing shame was key in healing ourselves and one another.

She found healing through gardening. Nurturing plants, working with life that depended on her, but was also grander than her, gave her perspective. She spent three years volunteering at Columbia River Correctional Institution in Portland with incarcerated people through garden based transformational education. She witnessed the walls break down for the inside gardeners as they discussed major life traumas while planting vegetables. Individuals who were once combative became collaborative, working with other inside gardeners with respect and openness. The garden became safe space that provided opportunity for self-reflection, vulnerability, and healing. In co-creating the garden they were transforming a little piece of land while transforming themselves. She connected with Smith Arthur while employed at Portland State University, prior to taking on her current position.

\section{Portland State University Capstone Program}

The courses described herein are offered through Portland State University. PSU places a heavy emphasis on engaged and applied research and learning. The Senior Capstone is one of these engaged learning opportunities; the final general education requirement for undergraduate students. Capstone courses are small, interdisciplinary, service learning seminars, and students collaborate together with a community partner. Academic content is paired with relevant 
service learning experiences. In most cases, seminars are limited to 16 students, allowing for relational and engaged learning (Kerrigan, 2015). Two of these Capstone courses allow incarcerated young people and college students to work collaboratively on service-learning projects that in some way benefit the community: the Juvenile Justice Capstone and Metamorphosis: Creating Positive Futures Capstone.

\section{Juvenile Justice Capstone}

The Juvenile Justice Capstone has a long standing partnership with the Multnomah County Department of Community Justice, Juvenile Services Division (DCJ), and specifically the juvenile detention facility - the Donald E. Long Home (DELH). As has been identified in scholarly examination of partnerships between higher education and carceral institutions, "the partnership is crucial in determining the success of the program" (Gould, Harkins \& Stevens 2015, p. 105). Having visited clients in juvenile detention and worked with juvenile court counselors from Multnomah County DCJ for a decade as a defense attorney, the instructor had established relationships with some key staff and administrators, which assisted in building the essential foundation for the partnership and the course. (Gould, et al, 2015). Despite those prior relationships, however, it was several years of working together before the partnership became as solid as it is currently. Although Multnomah County DCJ is relatively progressive and is a model site through the Annie E. Casey Juvenile Detention Alternatives Initiative, (https://multco.us/dcj-juvenile/jdai), when the relationship between PSU and DCJ was new, some detention staff were less that thrilled about an influx of college students into DELH. The students were sometimes seen as an addition to the workload for detention staff, causing some to be resentful of the partnership. Further, some staff were not proponents of creative and 
engaging opportunities for the youth in detention. While this tension can still exist, it is now thankfully greatly reduced, as the Capstone has been accepted as a part of the culture of DELH.

The youth detained in DELH are between the ages of 12-18, and are primarily being held pre-adjudication or pretrial in the case of Measure 11 youth. The average length of stay is 14 days, but youth can spend anywhere from 1- 241 days in the facility. Roughly 60 percent of youth in DELH at any given time are incarcerated under Oregon's Ballot Measure 11 (ORS 137.700, multco.us/dcj-juvenile, n.d.).

For the service-learning component of this course, Capstone students bring a writing and art workshop through a program called "The Beat Within: A Publication of Writing and Art From the Inside" ${ }^{[3]}$ into Multnomah County Juvenile Detention. ${ }^{[4]}$ In small groups, Capstone students get to know the youth on the various units throughout the detention facility and work closely with them each week to respond to prompts distributed to numerous juvenile facilities nationally by The Beat Within. The topics address a wide variety of issues, including personal as well as political and public policy issues.

For the detained youth who participate, these workshops provide an opportunity to have a voice beyond the walls of detention. Youth, through the Capstone students, submit pieces of writing and/or art to the editorial board of The Beat Within, and their work is considered for publication in the bi-monthly magazine. As indicated in their mission statement, The Beat Within "provide[s] incarcerated youth with consistent opportunity to share their ideas and life experiences in a safe space that encourages literacy, self-expression, some critical thinking skills, and healthy, supportive relationships with adults and their community" (http://www.thebeatwithin.org/about-us/). Affording young people the opportunity to build 
these relationships with the community and to tell their stories and engage in the public policy arena can be transformative for them (Tilton, 2013).

PSU Capstone students participate in this critical service-learning experience by engaging with the detained youth in prosocial ways and facilitating the weekly workshops; detained youth participate by sharing their own thoughts, experiences, and opinions with PSU students, the Beat Within magazine, and a broader audience of Beat Within readers.

Additionally, both sets of participants are asked to reflect critically on the underlying systemic issues related to juvenile incarceration. In sum, the collaborative critical service-learning project in the Juvenile Justice Capstone is the development of prosocial relationships between college students and incarcerated youth, and the community-engaged writing and art that occurs in the weekly workshops, finding a broad audience through The Beat Within magazine.

\section{Metamorphosis: Creating Positive Futures Capstone}

This Capstone course is an "Inside Out" ${ }^{[5]}$ course, bringing 15 PSU Capstone students into the Oregon Youth Authority’s (OYA) MacLaren Youth Correctional Facility (MYCF) in Woodburn, OR each week to study and learn together, side by side, in a collaborative and engaged learning community. ${ }^{[6]}$ MYCF is the largest OYA facility, all male, with 271 beds as of July 2017. A small percentage of people housed there are children ages 12-15; most are between 16 and 25. OYA houses people convicted as juveniles under Oregon’s automatic waiver law (Ballot Measure 11) who are officially in custody of the Department of Corrections (DOC), up until age 25. Overall length of stay in Close Custody averages 271 days for juveniles and 1356 days for DOC young men, and many of those move on to a DOC facility just prior to their 25th birthday to complete their sentence. $41 \%$ of people incarcerated in OYA are African American, while only 2.1 percent of Oregonians are African American. Not surprisingly, 
Hispanics and Native Americans are also overrepresented.

(http://www.oregon.gov/oya/docs/QuickFacts/QuickFacts-July2017.pdf;

https://www.census.gov/quickfacts/OR ).

Metamorphosis utilizes what Gould, Harkins and Stevens (2015) have termed $a$ participatory model, as the academic content is developed in collaboration with educators, students and non-profit staff within MYCF . The content of the course varies each term, as some of the inside students repeat the course, but always involves historical and contemporary examples of social justice movements. ${ }^{[7]}$ As part of the course requirements, students develop and implement a collaborative civic engagement project. The direction of the project changes each term, depending upon the course content and the current issues impacting students, but consistently the goal is for all students - inside and outside- to see themselves as agents of change in a broader community. For example, during one term, inside students alerted the class to their concern about the trees on the 100 plus year old MYCF campus. While at one time numerous trees adorned the campus, many of them had not been maintained well, were rotting, and were simply removed. The students, as a collective, decided to take action to address the preservation of the trees on the MYCF campus. They engaged in research and wrote a paper about why trees were important to personal wellbeing and rehabilitation as well as for the environment. Additionally, they petitioned OYA administration to preserve, maintain and add trees to the MYCF campus. Finally, students documented their efforts in a collaborative volume that also used trees as a metaphor for personal growth. ${ }^{[8]}$

In another term, the theme of the course was "where, why and how we live.” We studied gentrification and displacement, using Richard Rothstein's The Color of Law as our main text, and looked at how government policies created segregated neighborhoods. 
(Rothstein, 2017). For the collaborative project that term, students engaged in story sharing about their ideas of "home". These stories were recorded and became a radio show/podcast, serving to share with a broad audience students' thoughts and stories related to our course content, and secondarily, almost as a by-product, sharing the power of our collaborative inside/out community. In each of these examples, the projects evolved naturally out of discussion around the course content and examination of various ways that all students, inside and outside, could collaborate as change agents and have a meaningful impact on a topic of shared concern.

\section{Reflection as a pedagogical tool in effective critical service learning}

A key component of critical service-learning as a tool for transformation involves reflective process. Learning through experience is not necessarily intuitive; supporting learners to reflect critically upon their experiences before, during and after their service-learning experiences can deepen and solidify the associated learning (Coulson \& Marina, 2013). Maximal learning occurs through not just the experience alone- but through critical reflection upon the experience (Ash \& Clayton, 2009). Additionally, as students and participants are asked to reflect upon the larger complex structural roots that surround and contextualize the critical service-learning experience, the engaged learning experience for all participantscollege students and incarcerated students and participants alike - moves beyond personal and/or social development, and into the realm of social change activism. Indeed, "[e]xperience becomes educative when critical reflective thought creates new meaning and leads to growth and the ability to take informed actions” (Bringle \& Hatcher, 1999, p. 180).

In both of these Capstone courses, students and participants are asked to reflect through writing and discussion on the deeper causes and contexts of their work. Beyond doing good 
work that will benefit the broader community, students are asked to think critically about attitudes and policies that create the conditions surrounding their work. In both of these courses, through collaborating with the "other", in this case incarcerated youth, or college students, and then by critically reflecting upon that experience, students and participants are able to understand criminal and juvenile justice, higher education, and social justice issues in a deeper way than they could by simply reading about the content area, or experiences of the other. It is not uncommon for students to be impacted emotionally as well as intellectually by the experience. Through reflective writing assignments, students are asked to connect their experiences and their feelings about those experiences to the course content, related policy, and to identify, document and reflect upon their own growth as a result. In both courses, the term ends with a Closing Circle, a final session involving all students, participants, the instructor, and staff in the facilities, during which all in the circle are asked to identify and share what the experience of learning and working together has meant for them- how they have grown as a result of the experience of the course.

\section{Impact of collaborative service-learning}

Through this qualitative research study, we attempt to contribute to generalizable knowledge about university partnerships with carceral institutions, specifically through these two courses involving collaborative critical service-learning projects between college students and incarcerated students and participants. Relying upon Creswell's (1994) model of qualitative research, the researchers conducted data analysis using reflective writing in the form of short essay and poetry, created and submitted by both inside students and participants and outside students over the course of four terms in both the Juvenile Justice Capstone and the Metamorphosis: Creating Positive Futures Capstone. These documents were analyzed and 
evaluated through the lens of predetermined criteria for both outside students and inside students. Researchers independently identified emerging themes expressed throughout the reflective writing for the following evidence. For outside or University students, papers were reviewed for evidence of “interrupted assumptions” connected to working together with inside or incarcerated students. For inside incarcerated students, reflective writings were analyzed for evidence of increased “motivational capital”: evidence of increased social and cognitive resources developed as part of these service-learning experiences working together with outside students.

\section{Participants}

Our study contains two classifications of participants: “outside,” Portland State University students, and “inside” students and participants from DELH and MYCF. Students from both Portland State University, MYCF, and DELH enrolled or participated in each class autonomously, by choice, and based on individual interest in the subject matter and course concept.

\section{Methods}

To conduct this research, reflective writing previously submitted by students and participants in both Capstone courses during the four terms were randomly selected, pulling 40 papers from outside PSU students and 40 papers from inside MCYF students across the eight classes, totaling 80 data samples. After random selection of data, all identifiers were removed from the reflection papers and replaced with either "incarcerated student” or "PSU student." These de-identified papers were independently analyzed by researchers to understand the effect of service learning for both outside PSU students and incarcerated MCYF students. Each researcher read through the 80 reflection documents, reviewing the data and noting emerging 
themes. The researchers confirmed and verified results of the data in what Patton (1990) describes as content analysis, categorizing data patterns into themes and topics. Researchers noted several key themes in the writings of both incarcerated students and University students highlighting specific beneficial components of service learning, discussed in detail below.

\section{Analysis}

In conducting thorough content analysis and review of the data, researchers evaluated critical service-learning courses in which college students and incarcerated youth collaborate together, identifying themes that demonstrated impact. For outside students, evidence of interrupted assumptions were examined. Specifically, questions entering into the research were: has collaborating with incarcerated youth re-shaped college students’ ideas about people who are incarcerated and re-entering? Is there evidence of a deeper understanding of the underlying complexities of the juvenile and criminal justice systems? Can evidence of a shift in attitudes toward political issues surrounding society’s response to crime through mass incarceration be found? In the incarcerated students and participants reflections and writings, data were examined for evidence of increased motivational capital as a result of these collaborative critical service-learning experiences with outside students. Specifically, through these courses, are incarcerated students and participants developing prosocial skills and relationships? Are they developing awareness of themselves as agents of change in society? Is there evidence of increased social and cognitive resources resulting from working together with college students in service-learning courses?

\section{Summary of Findings: Outside Students}

After reviewing the 40 reflection essays and poems from PSU Capstone students, several clear themes emerged. Overall, many of the students discussed how they had negative 
preconceived notions regarding the incarcerated students; however, through meeting and collaborating together, these ideas were dismantled. By the end of the term, PSU students had a completely different perception of who is incarcerated, commenting on the intelligence, passion, and humanity of their fellow incarcerated classmates. Specifically, four main themes emerged throughout the writing of outside students which were a direct result of service learning and collaboration with incarcerated students. First, the outside students see the inside students as more than their crime and as capable individuals full of potential. Outside students also commented on similarities between the two student groups, identifying privilege and mentorship as a key factor in either success or incarceration. Third, PSU students discussed the importance of connection and the power of collaboration. Finally, after embarking on this educational journey, outside students had a newfound commitment to social justice and advocacy for the rights of their incarcerated classmates.

\section{More than their crime, shifting perspectives}

Upon reflection at the close of the 10 week class, outside students described how different their perspective was from the beginning of the class, and how much they had transformed as individuals. One PSU student shares about previous conversations with her family, who had urged her not to enter a correctional facility, fearing for her safety. Other students commented about feeling nervous, expecting the worst from their incarcerated classmates, envisioning monsters rather than teens. However, through engaging in learning opportunities together, the dialog of who is incarcerated began to change. As one student states, “My fixed idea about who these inmates were supposed to be were challenged.” Inside students were seen as, “fellow academic scholars” intellectually capable, and full of compassion, caring, 
and having an ability to change. As one student reflects, “a person’s past does not write their future,” and these incarcerated students have unique perspectives to offer society.

\section{Realizing similarities}

Outside students remarked on similarities between themselves and the inside students and participants. Several noted that the only thing that separated them was wearing a visitor badge. Because of mentorship and support from family, outside students had advantages that their incarcerated peers did not. Students acknowledged that with only a small change in circumstance roles could have been reversed, "if one thing had been tweaked slightly in my life, I could have easily ended up where these guys are today. There is nothing separating me from them in terms of worthiness.” Upon realizing their similarities, students were able to connect on a deeper level, breaking down barriers separating “us” and "them,” and build egalitarian relationships.

\section{Power of the group/Importance of community}

Another theme that clearly emerged was a strong sense of the importance of community connection and power of collaboration. Many PSU students indicated through their reflective writing that they found power in the diversity of the group, and found that the experiences, skills and perspectives that all contributed made for a stronger and more powerful outcome. As so beautifully stated by one student: “Helping one another and peacefully coexisting is what enriches our lives.”

\section{Deeper understanding and desire to create change}

After learning in a general way about the background of their incarcerated classmates, and through class readings and discussions about privilege, power, and the school to prison 
pipeline, outside students felt a commitment to improving the welfare of those impacted by incarceration. They gained empathy for their classmates and individuals in society whose circumstances gave them an increased chance of being sent to prison. One PSU student writes after learning about privilege and access to social capital, "I felt enraged! I was furious to be a part of a system that blatantly neglects those that it predetermines will have no gifts to give and nothing to offer.” Through learning about the larger system and listening to the stories of their incarcerated classmates, outside students realized the deeper complexities around incarceration and described a deep desire to dismantle unfair social structures which keeps specific populations marginalized. As one student advocates, "This newfound information has prompted me to look further into policies and practices that disproportionately result in the incarceration of minorities, and marginalized members of our society.” Another student states: “I am astounded at the young bright minds trapped in this facility.” These students will become the next generation of leaders and changemakers, challenging the current status quo.

\section{Summary of Findings: Inside Students and Participants}

In reviewing the data extracted from reflective documents of the incarcerated students and participants (insiders), three major themes emerged: the power of, and gratitude for, the group; a new or strengthened commitment to civic engagement and a sense of civic responsibility; and personal transformation and a new or renewed sense of hope about the future. Each of these themes is discussed in depth below.

\section{Power of the group/Importance of community}

As is true for the outside students, many insiders also expressed that they were impressed by and grateful for the power of a group of people from varied backgrounds working together toward a common goal. They seemed to derive energy and strength from this 
collaborative process, and, at the very least, found it to be enjoyable and a pleasurable break in the routine of a life of incarceration. One insider indicated: "one person can only be so strong, but a group of people are a collective force of achievement.” Another states: "I learned that on my own I am nothing... however when I am able to connect with others around me I am part of something so much bigger.” Insiders enjoyed the experience of meeting each week with their colleagues from the outside. Comments indicate appreciation for getting to know and interact with new people, and great pleasure in "sharing with the outside students what it's like on the inside.” Insiders expressed gratitude “that we can all learn from each other.” Yet another aspect of the benefit of the group collaboration that inside students and participants felt was a sense that they were no longer isolated. They appreciated that their voices could extend beyond the walls of incarceration. In the words of one insider, "It's really good that people care about us. A lot of people forget about us, so we appreciate when you come in.”

\section{Civic engagement and responsibility}

Another theme to emerge from the data extracted from insiders' reflective writing was a new or strengthened commitment to civic engagement. Many youth documented this new or renewed concern for the greater civic good, and found excitement and a sense of efficacy and empowerment in that. They were excited that "through this class we were able to make change,” and "we were proactive in ways outside of the classroom.” Insiders expressed a desire to continue their activism after community reentry. Many reflected upon what they can do to "make this world a better place," and indicated a desire to apply what they had learned about content, about themselves- to be a part of "fixing problems" in the world. Poignantly, another insider stated that the experience of collaborating with the PSU students, "made me feel like I still matter out in the world beyond the fence.” 


\section{Personal transformation and hope}

Finally, the third theme to emerge from the data of the insiders was the idea that they had been personally impacted in important ways by their participation in the collaborative service-learning project, and that they had found a new or stronger sense of hope about their future as a result. As one incarcerated young person clearly states: “[t]here is hope for a better tomorrow.” A shift in identity seems to have emerged. Incarcerated students and participants remarked that as a result of the class experience, they felt "more like a human being and less like a convict.” They had developed or strengthened a compassion for others, and now had a “ better outlook on life and the people around [them].” The experience of the collaboration with the college students had “opened [their] feelings up.” There was a sense that "when I get out I can make it.” From the poem of one insider: "with vision of walls and bars, we still unstoppable, our voices rise.”

\section{Discussion}

Through this analysis of reflective writings of both PSU students and incarcerated student participants, it is clear that these collaborative critical service-learning experiences have powerful impacts for both groups. For the university students, assumptions about those experiencing incarceration is indeed challenged and interrupted as a result of working together with the inside students and participants. Perceived barriers fall away and wakefulness is cultivated in this unfamiliar territory in which university students collaborate for change with young incarcerated people inside the carceral setting. The shared experience thus becomes fertile ground for new perceptions and discoveries. As Lori Pompa, the founder of the Inside Out Prison Exchange Program, articulated so poetically, within these shared engaged learning experiences "countless life lessons and realizations surface about how we as human beings 
operate in the world, beyond the myths and stereotypes that imprison us all” (Pompa, 2005, p. 176). Additionally, outside students become engaged in a deep way with unpacking and challenging the underlying complexities of the juvenile and criminal justice systems. The context of the course- the collaboration with incarcerated young people, the physical learning space inside the razor wire, the readings and reflections - creates the potential for thinking critically and creatively about these systems.

There are likewise positive outcomes for incarcerated students and participants. Beyond receiving college credit, the research illuminated evidence of increased motivational capital and an increased sense of hope and positive expectations for their "future selves" as a result of these courses. Imagining an improved future self in turn provides motivation for action to develop strategies that can help make that vision a reality (Clinkinbeard \& Zhora, 2012). This belief in self improvement is a powerful force as Bernstein (2014) elaborates, "When a captive speaks of hope, he's talking of a strategy as much as an emotion: a technique to stay human in an environment designed to dehumanize him” (p. 93). In developing pro-social tools to remain connected, incarcerated students increase their connectivity to the outside community. In addition, there is evidence of students and participants on the inside increasing or developing a sense of responsibility and an eagerness to positively impact the world. In her recent book highlighting the imperative of access to higher education for people experiencing incarceration, Lagemann (2016) addresses the importance of this outcome, affirming that "[c]ollege in in prison programs promote civic competence and support student aspirations to make a positive difference for other people” (p.95). These critical and collaborative service-learning courses do in fact result in increased self perceptions as agents of change, providing motivational capital through the pro-social egalitarian relationships built, the appreciation of the power of the group, 
the personal feelings of hope and transformation, and the desire to take action to address social justice issues.

Our research is in alignment with existing research in this area. Previous research indicates that for young people experiencing incarceration, partnerships such as the ones created in these two courses, allowing for face to face interactions and shared civic engagement responsibilities, offer an increased sense of community engagement, and a decrease in feelings of isolation (Catching, 2013; Hinck \& Hinck, 2013). Indeed, “[e]ngaging young people in changing their communities may be a more powerful and successful way of getting young people to change themselves than efforts that focus on individual rehabilitation” (Tilton, 2013, p.1195). Through engagement with college students from the outside, young people are supported in constructing a different narratives for themselves (Nurse, 2013). These findings are also in alignment with Allred, Harrison and O’Connell (2013) who noted a statistically significant increase in self-efficacy for inside students of higher education courses offered via an Inside Out format (2013). Shoemaker, Willis \& Bryant (2014) also write about education and knowledge in carceral settings as being a key component of transforming one’s perspectives and opportunities.

\section{Limitations}

While it was clear that themes emerged from the research, the reflection essays examined did not adequately represent the rich discussions that occurred in class. Some of the samples drawn from the Juvenile Justice Capstone were based upon prompts from The Beat Within unrelated to the questions posed in this research, thus somewhat limiting the data set from that course. Also, during class collaborations, discussions, and closing circles, students and participants engage in rich, thought provoking, and transformational dialog which sadly 
was not captured and analyzed in this research. To accurately reflect the essence of class impact, researchers suggest posing prompts that enable students to specifically articulate the significance of collaborative critical service learning. In future research, surveys and interviews of students and participants would allow an even deeper understanding of the impact of the experience.

Also problematic is the fact that the sample included only a very small number of female participants. Because MYCF is all male, and only one unit in DELH houses females, the female voice and perspective is largely unheard, and this is a large and unfortunate omission.

\section{Conclusion}

Partnerships involving higher education and carceral institutions, particularly when they involve collaborative critical service-learning courses are "win/win” in that they result in significant positive impacts for all students and participants, and allow a new way of imagining our nation's policies of mass incarceration. As stated by Sarah Allred, associate professor of sociology and department chair at Berry College, in Mt. Berry, Georgia, "one of the greatest things that comes out of these types of classes is the confidence that both groups of students feel after completing them and the culture of positivity that they promote.” (Lalji, 2015). Courses such as these can and should be more broadly offered and available. Opportunities that enable students and participants from diverse backgrounds, facing difficult life struggles, to work together to bridge perceived differences and impact social justice issues create a community of change. As one student eloquently states, "In a course focused on bringing together groups of people from seemingly different places, I think we found that we were more alike than different. We are all humans in this world, and we are all responsible for working together, and approaching each individual with a sense of acceptance and understanding. We shouldn't let 
our experiences define us, but rather use them as tools to help increase our level of

understanding and awareness of the world around us, and put those experiences to good use” (Outside student, Metamorphosis Capstone).

\section{References}

Allred, S.L., Harrison, L.D., \& O’Connell, D.J. (2013). Self efficacy: an important aspect of prison based learning. The Prison Journal, 93(2), 211-233.

doi:10.1177/0032885512472964

Arthur, D.S., Ed. (2015) Metamorphosis: creating positive futures. Self Published, Blurb.com http://www.blurb.com/b/6599006-metamorphosis-creating-positive-futures

Ash, S. L., \& Clayton, P. H. (2009). Generating, deepening and documenting learning: The power of critical reflection in applied learning. Journal of Applied Learning in Higher Education, 1, 25-48.

Astin, A.W., Vogelgesang, L.J., Ikeda, E.K., \& Yee, J.A. (2000). How service learning affects students. UNO Digital Commons at UNO. Retrived from http://digitalcommons.unomaha.edu/cgi/viewcontent.cgi?article=1145\&context=slcehigh ered

Bazemore, G. \& Boba, R. (2007) "Doing Good” to "Make Good”: Community Theory for Practice in a Restorative Justice Civic Engagement Reentry Model. Journal of Offender Rehabilitation, 46(1-2), 25-56. doi: 10.1080/10509670802071493

Bazemore, G. \& Maruna, S. (2009). Restorative Justice in the Reentry Context: Building New Theory and Expanding the Evidence Base. Victims \& Offenders, 4(4), 375-384, doi: $10.1080 / 15564880903227446$

Bernstein, N. (2014). Burning Down the House: The End of Juvenile Prison. New York: The New Press.

Bringle, R. G., \& Hatcher, J. A. (1999). Reflection in service learning: Making meaning of experience. Educational HORIZONS Evaluation/Reflection, 23, 179-185. Retrieved from http://digitalcommons.unomaha.edu/slceeval/23 
Catching, L. (2013). The Beat Within: Perceptions and attitudes among youth and volunteers - A conversational survey of Santa Clara, Solano and San Francisco Facilities. Unpublished research. UC Irvine.

Christianakis, M., \& Mora, R. (2016). (Re)writing Identities: Past, Present, and Future Narratives of Young People in Juvenile Detention Facilities, Life Writing, DOI: 10.1080/14484528.2016.1138568

Clinkinbeard, S. \& Zohra,T. (2012). Expectations fears and strategies: Juvenile offender thoughts on a future outside of incarceration. Youth and Society, 44(2), 236-257.

Coulson, D. \& Harvey, M. (2013). Scaffolding student reflection for experience-based learning: a framework. Teaching in Higher Education, 18(4), 401-413. Retrieved from http://dx.doi.org.proxy.lib.pdx.edu/10.1080/13562517.2012.752726

Creswell, J. W. (2013). Research Design: Qualitative, Quantitative, and Mixed Methods Approaches (4th Ed.). Los Angeles: Sage Publications.

Eyler, J., Giles, D. E. Jr., Stenson, C. M., \& Gray, C. J. (2001). At A Glance: What We Know about The Effects of Service-Learning on College Students, Faculty, Institutions and Communities, 1993- 2000 (3rd Ed.). Higher Education, Paper 139. Retrieved from http://digitalcommons.unomaha.edu/slcehighered/139

Flanagan, C. \& Levine, P. (2010). Civic Engagement and the Transition to Adulthood. Future of Children, 20(1) 159-180.

Fox, K. J. (2016). Civic commitment: promoting desistance through community reintegration. Punishment and Society, 18(1), 68-94. doi:10.1177/1462474515623102

Fox, K. J. (2015). Theorizing community integration as desistance promotion. Criminal Justice and Behavior, 42(1), 82-94.

Freire, P. \& Macedo, D. (1998). Literacy: Reading the World. Westport: Bergin \& Garvey.

Gould, M., Harkins, G., \& Stevens, K. (2015). College Civic Engagement and Education Behind Bars: Connecting Communities, Creating Change. In R. Scott. (Ed.), Bringing college education into prisons: new directions for community colleges, number 170. Retrieved from https://ebookcentral-proquest-com.proxy.lib.pdx.edu

Gruenewald, D. A. (2003). The Best of Both Worlds: A Critical Pedagogy of Place. Educational Researcher, 32(4), 3-12. doi: 10.3102/0013189X032004003

House, V. (2015). Community engagement in writing program design and administration. 
WPA: Writing Program Administration - Journal of the Council of Writing Program Administrators, .39(1), 54-71.

Hinck, S.S., Hinck, E.A., \& Withers, L.A. (2013). Service-Learning in Prison Facilities: Interaction as a Source of Transformation. In S.J. Hartnett, E. Novek, E., \& J.K. Wood (Eds.), Working for Justice: A Handbook of Prison Education and Activism. (pp. 39-59). Urbana: University of Illinois Press.

Kerrigan, S. (2015). Sustaining change: successes, challenges and lessons learned from twenty years of empowering students through community-based learning Capstones. Metropolitan Universities, 26(3), 11-32.

Lagemann, E. C. (2016) Liberating Minds: The Case for College in Prison. New York:The New Press.

Lalji, N. (2015) School Behind Bars: How College Kids and Incarcerated Youth Benefit from Learning Together. Yes! Magazine http://www.yesmagazine.org/peace-justice/school-behind-barsdeborah-arthur-inside-out-20150812

Maruna, S., LeBel T. P., \& Lanier, C.S. (2004). Generativity behind bars: Some "redemptive truth" about prison society in De Saint Aubin. In D. McAdams, D. Te-Chang, \& K. TeChang (Eds.), The Generative Society: Caring for Future Generation (pp. 131-151). Washington, D.C.: US American Psychological Association.

Mitchell, T. D. (2008). Traditional vs. critical service-learning: Engaging the literature to differentiate two models. Michigan Journal of Community Service Learning, 14(2), 5065. Retrieved from http://hdl.handle.net.proxy.lib.pdx.edu/2027/spo.3239521.0014.205

Mitchell, T. D. (2015). Using a critical service-learning approach to facilitate civic identity development. Theory Into Practice, 54, 20-28. doi: 10.1080/00405841.2015.977657

Moely, B. E. \& Ilustra, V. (2014). The Impact of Service Learning Course Characteristics on university students’ learning outcomes. Michigan Journal of Community Service Learning, 21(1), 5.

Nurse, A.M. (2013). Juveniles and college: Inside Out as a way forward. The Prison Journal, 93(2) 234-247.

Patton, M.Q. (1990). Qualitative evaluation and research methods. Newbury Park: Sage Publications.

Pompa, L. (2005). Service learning as crucible: Reflections on immersion, context, power and transformation. In D.W. H. Butin (Ed.), Service Learning in Higher Education: Critical Issues and Directions (pp. 67-76). New York: Palgrave Macmillan.

Rothstein, R. (2017). The Color of Law: A Forgotten History of How Our Government 
Segregated America. New York: Liveright Publishing.

Shoemaker, D., Willis, B., \& Bryant, A. (2014). We are the products of our experiences: the role higher education plays in prison. Journal of Prisoners on Prisons. 23(1), 31-55.

Simpkins, B. (2015). College Inside: A case study of the design and implementation of a successful prison college program. In R. Scott, (Ed.). Bringing college education into prisons: new directions for community colleges, number 170. Retrieved from https://ebookcentral-proquest-com.proxy.lib.pdx.edu

Sokoloff, N.J. \& Schenck-Fontaine, A. (2017). College programs in prison and upon reentry for men and women: a literature review. Contemporary Justice Review, 20 (1).

Tilton, J. (2013). Rethinking youth voice and institutional power: Reflections from inside a service learning partnership in a California juvenile hall. Children and Youth Service Review 35, 1189-1196. 